\title{
Pengembangan E-Book Mata Kuliah Drama sebagai Media Pembelajaran Mandiri di Masa Pandemi
}

\author{
Liza Septa Wilyanti*, Larlen, Irma Suryani \\ Universitas Jambi \\ “Correspondence email: liza.septa@unja.ac.id; larlen10@gmail.com; irmasuryani@unja.ac.id
}

\begin{abstract}
Abstrak. Penelitian ini bertujuan untuk mengembangkan e-book mata kuliah Drama yang dapat digunakan secara mandiri oleh mahasiswa dengan menautkan video pembelajaran yang telah diunggah oleh dosen di media youtube. Pengembangan e-book mata kuliah Drama ini bertujuan untuk membantu dan menunjang pembelajaran jarak jauh, terutama di masa pandemi ini. Penelitian ini mengikuti langkah ADDIE (analize, design, develop, implement, dan evaluate) yang berfokus pada penelitian pengembangan. Berdasarkan hasil analisis data, rata-rata nilai tiap aspek yang diuji dalam e-book mata kuliah Drama ini adalah 83,85. Angka ini menunjukkan buku ajar pada Mata Kuliah Drama layak dan valid untuk digunakan. Efektifitas dan praktikalitas $e$-book mata kuliah Drama yang telah digunakan memperoleh nilai rata-rata 83,25. Angka ini menunjukkan $e$-book mata kuliah Drama praktis dan efektif untuk digunakan dalam pembelajaran.
\end{abstract}

Kata kunci: Drama; E-book; Media Pembelajaran

Abstract. This research aims to develop an eBook of Drama courses that can be used independently by students by linking learning videos that have been uploaded by lecturers in youtube media. The development of drama e-book courses aims to help and support distance learning, especially during this pandemic. This research follows the steps of ADDIE (analize, design, develop, implement, and evaluate) which focuses on development research. Based on the results of data analysis, the average value of each aspect tested in the eBook of this Drama course is 83.85. This figure shows the teaching book on Drama Subjects is feasible and valid to use. The effectiveness and practicality of the e-book drama courses that have been used obtained an average score of 83.25. This figure shows the Drama course eBook is practical and effective for use in learning.

Keywords: Drama; E-book; Learning Media

\section{PENDAHULUAN}

Pembelajaran drama di perguruan tinggi tidak hanya melingkupi pengajaran teori drama, namun juga terkait pengajaran keterampilan bermain drama. Keterampilan bermain drama wajib dikuasai oleh mahasiswa sebagai calon guru Bahasa Indonesia nantinya. Pembelajaran bermain drama merupakan sarana efektif bagi guru untuk menanamkan nilai-nilai pendidikan karakter dengan cara yang menyenangkan kepada siswa.

Salah satu ciri implementasi KKNI dalam proses pembelajaran adalah pembelajaran yang berpusat pada mahasiswa. Metode ceramah memang tidak tepat digunakan pada mata kuliah keterampilan seperti bermain drama. Oleh sebab itu, metode pembelajaran harus dialihkan dari teacher-centered menjadi student centered (Fajria, 2018). Keaktifan dan penguasaan keterampilan adalah capaian pembelajaran yang harus dikuasai oleh mahasiswa. Dosen dapat menggunakan berbagai bentuk instrumen pembelajaran yang efektif agar dapat menunjang keaktifan dan pemahaman mahasiswa dalam proses pembelajaran. Pembelajaran dikatakan efektif apabila tidak hanya memberikan dampak instruksional, tetapi juga memberi dampak pengiring positif (Anisa, 2019). Proses praktik yang dialami langsung oleh mahasiswa akan meningkatkan keterampilan, penguasaan dan timbulnya kesenangan (Puspitasari dkk, 2016). Oleh sebab itulah, pengembangan buku ajar tidak hanya dapat membantu meningkatkan keterampilan bermain drama mahasiswa, tetapi juga memberi dampak pengiring positif, yaitu membangun budaya pembelajaran secara mandiri. Tugas mengembangkan bahan ajar sendiri merupakan kewajiban bagi dosen yang mengampu mata kuliah tertentu (Murti \& Muhtadin, 2019).

Pada pembelajaran sastra, termasuk drama, nilai estetika harus tergambar dan tersampaikan kepada mahasiswa (Khaerudin dkk, 2019). Selain itu, sastra juga berhubungan erat dengan kemampuan berbahasa mahasiswa. Sastra lebih lanjut dapat memperkaya, memperdalam, memperluas daya pikir, daya analitis kritis dan imajinasi. Oleh sebab itu, capaian pembelajaran sastra harus tersampaikan dengan optimal (Piscayanti, 2012). Berbeda dari prosa dan puisi yang langsung dapat dinikmati pembaca saat disajikan, drama lebih memberi ruang imajinasi kepada pembaca (Suryanto, 2016).

Guna mengoptimalkan imajinasi dalam pembelajaran drama, pengembangan dan ketersediaan bahan ajar yang baik dan mandiri harus tersedia. Pengembangan bahan ajar mata kuliah sastra, khususnya drama harus memperhatikan betul unsur-unsur dalam drama sehingga kompleksitas pembelajaran keterampilan drama secara mandiri terutama bagi mahasiswa yang belajar virtual dari rumah dapat 
terpahami dengan baik dan benar (Pudyastuti dkk, 2015).

Pengembangan buku ajar yang mandiri dapat memanfaatkan media lain yang dapat diakses mahasiswa secara relatif mudah. Media Youtube dapat dijadikan alternatif tersebut. Hal ini dikarenakan selain popular dikalangan muda, media youtube juga merupakan media yang memiliki keunggulan baik audio maupun visual. Untuk itu, perlu adanya kreativitas dan inovasi dosen dalam mengembangkan buku ajar sebagai salah satu bentuk bahan ajar. Bahan ajar dapat dikembangkan oleh dosen atau guru untuk membantu proses kegiatan belajar mengajar (Aji dkk, 2017). Bahan ajar yang dikembangkan seharusnya dapat disesuaikan dengan kebutuhan, terutama di masa pendemi saat ini. Bahan ajar yang dikembangkan oleh dosen harus dapat memuat segala bentuk bahan, informasi, alat, maupun teks yang diperlukan guru untuk mencapai tujuan perkuliahannya (Jannah \& Muhammad, 2015). Selain itu, bahan ajar yang dikembangkan oleh dosen harus pula memperhatikan prinsip-prinsip pembelajaran yang berpusat pada mahasiswa (Ghufroni \& Toharudin, 2020).

Sejak virus Corona atau Covid-19 ditetapkan sebagai wabah nasional, pembelajaran di berbagai tingkat satuan pendidikan mulai berdaptasi. Melalui siaran pers Nomor:137/sipres/A6/VI/2020, Kementerian Pendidikan dan Kebudayaan bersama Gugus Tugas Percepatan Penanganan Covid-19, Kementerian Pembangunan Manusia dan Kebudayaan, Kementerian Agama, Kementerian Kesehatan, Kementerian Dalam Negeri, Badan Nasional Penanggulangan Bencana, dan Komisi X DPR RI mengumumkan rencana Keputusan Bersama Empat Kementerian tentang Panduan Penyelenggaraan Pembelajaran pada Tahun Akademik Baru di masa pandemi.

Keputusan Bersama Empat Kementerian tentang Panduan Penyelenggaraan Pembelajaran pada Tahun Akademik Baru di masa pandemi memutuskan setiap perguruan tinggi di semua zona wajib dilaksanakan secara daring, baik itu mata kuliah teori maupun praktik. Akan tetapi, bagi mata kuliah praktik yang tidak dapat dilakukan secara daring, aktivitas praktik langsung dapat dilakukan di akhir semester dengan tetap memperhatikan protokol kesehatan dan jumalh mahasiswa yang dibatasi.

Keterampilan bermain drama menuntut mahasiswa mampu memiliki keterampilan vokal, semantik, fonetik, dan sosial yang baik (Nainggolan \& Erni, 2019). Pembelajaran Drama di perguruan tinggi termasuk mata kuliah praktik yang masih dapat dilakukan secara daring. Akan tetapi, hal tersebut bukan berarti tugas dosen menjadi lebih ringan. Justru pengajaran mata kuliah Drama secara daring mengharuskan dosen untuk mempersiapkan media pembelajaran yang valid, efektif, dan praktis dalam penggunaannya. Dosen memiliki tanggung jawab agar mahasiswa dapat memahami, mengapresiasi, bahkan menghasilkan karya sendiri (Hetami, 2010). Salah satu media yang dapat dikembangkan adalah e-book mata kuliah Drama. Buku elektronik dapat disebarluaskan kepada mahasiswa melalui internet sehingga memudahkan dosen dalam pengajaran dan memudahkan mahasiswa pula dalam pembelajaran mandiri. Tautan video pembelajaran yang terdapat di dalam $e$-book dapat langsung diakses melalui internet. Penggunaan internet untuk mengunduh e-book dan streaming video pembelajaran di internet memang memerlukan kuota. Akan tetapi, hal tersebut diasumsikan telah mendapat solusi melalui adanya bantuan paket kuota dari Kemendikbud kepada dosen dan mahasiswa. Mengembangkan buku ajar berbentuk elektronik atau $e$ book merupakan salah satu cara untuk memperbaiki proses dan hasil pembelajaran. Pengembangan buku ajar harus disesuaikan dengan situasi dan kondisi (Suryani \& Rasdawita, 2018).

Tomlinson (2011) menjelaskan bahwa "bahan ajar pembelajaran bahasa dapat terfasilitasi melalui berbagai bahan. Bahan ajar dapat terdiri dari video, buku teks, DVD, YouTube, email, native speaker, intruksi pendidik/guru, dan lain sebagainya”. dalam perkembangannya, buku teks ini telah dapat dialihbentukkan kedalam media buku digital atau $e$ book. "Bahan ajar sebagai segala bentuk bahan berupa seperangkat materi yang disusun secara sistematis untuk membantu peserta didik dan pendidik/guru dalam melaksanakan kegiatan pembelajaran dan memungkinkan peserta didik untuk belajar" (Kurniasih dkk, 2014). Lebih lanjut, Zahroh (2017) memaparkan bahwa bahan ajar merupakan segala bahan yang berisi materi dan telah disusun secara sistematis sehingga pembelajaran dapat berjalan dengan baik. Bahan ajar adalah segala bentuk bahan yang digunakan untuk membantu pendidik/guru atau instruktur dalam melaksanakan proses pembelajaran di kelas.

E-book dapat menjadi salah satu bahan ajar yang dipersiapkan dalam pembelajaran daring bersama mahasiswa. E-book biasanya bersifat mandiri, artinya dapat dipelajari oleh mahasiswa secara mandiri karena sistematis dan lengkap sama seperti buku ajar fisik pada umumnya. "Buku ajar dirancang dengan prinsip-prinsip pembelajaran, sesuai dengan urutan pembahasan yang sistematis, memotivasi mahasiswa untuk belajar, memberikan latihan, dan berorientasi pada mahasiswa secara individual" (Soleh \& Muhammad, 2013). Buku teks perlu disiapkan oleh pakar atau ahli pembelajaran di bidang tertentu agar sesuai dengan maksud dan tujuan pembelajaran yang ingin dicapai. Menurut Prastowo (2014), "tujuan pembelajaran terdiri atas empat hal, yaitu membantu peserta didik mempelajari sesuatu, mencegah rasa bosan, memudahkan pembelajaran, dan membuat pembelajaran menjadi lebih menarik." E-book diasumsikan dapat memenuhi keempat aspek tersebut karena dilengkapi dengan video pembelajaran. 
Mahasiswa dapat langsung mempraktikkan gerangerakan latihan secara langsung dan terstruktur.

\section{METODE}

Penelitian pengembangan e-book mata kuliah Drama termasuk ke dalam jenis penelitian Research and Development atau penelitian dan pengembangan. "Metode penelitian pengembangan digunakan untuk menghasilkan produk tertentu" (Sugiyono, 2010). Penelitian ini mengadopsi model ADDIE analyse, design, develop, implement, and evaluate) yang dikembangkan oleh Robert Maribe Branch (2009). Adapun desain penelitian pengembangan (research \& development) akan dilakukan seperti tampak pada pada desain berikut.

Pada tahap awal, Peneliti melakukan identifikasi dan analisis tentang materi apa saja yang diperlukan oleh mahasiswa dan dosen untuk menunjang proses pembelajaran drama secara mandiri baik teori maupun praktik. Setelah dilakukan analisis, peneliti mulai merancang materi pembelajaran yang akan dikembangkan dan dibukukan menjadi e-book yang layak dan efektif untuk dugunakan dalam proses pembelajaran drama di perguruan tinggi.

Pada tahap pengembangan, peneliti mulai mengembangkan draf e-book menjadi beberapa bab materi dan dikonslutasikan kevalidan, keefektifan, serta kepraktisannya bersama beberapa ahli di bidang pembelajaran. E-book yang telah disusun dan dikembangkan selanjutnya diimplementasikan dalam pembelajaran pada mata kuliah Drama untuk diketahui bagaimana tingkat praktikalitas dan efektivitasnya. Pada tahap akhir ini, dilakukan evaluasi terhadap e-book yang telah coba diimplementasikan kepada mahasiswa. Apabila terdapat kekurangan atau kesalahan, akan dilakukan revisi untuk proses penyempurnaan.

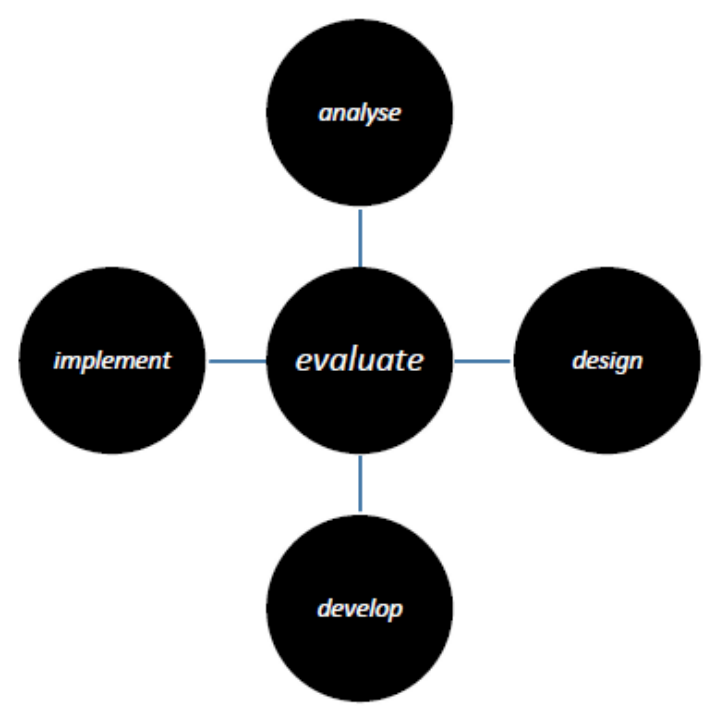

Gambar 1. Desain Penelitian Pengembangan ADDIE (Branch, 2009)
Data penelitian ini adalah data kuantitatif dan kualitatif berupa hasil penyebaran angket tertutup dan hasil validasi ahli. Sumber data dalam penelitian ini adalah RPS, angket tertutup, dan lembar validasi. Instrumen penelitian yang digunakan untuk pengumpulan data berupa lembar validasi oleh ahli dan lembar angket tertutup dari mahasiswa untuk mengetahui apakah e-book yang telah dikembangkan sudah dianggap efektif dan praktis. Data yang telah didapat dari proses validasi ahli dan penyebaran angket kepada mahasiswa nantinya akan dianalisis dengan rumus berikut.

$$
\text { Nilai yang diperoleh }=\frac{\text { skor yang diperoleh }}{\text { skormaksimal }} \times 100 \%
$$

\section{HASIL DAN PEMBAHASAN}

Pengembangan e-book mata kuliah Drama pada hakikatnya disesuaikan dengan capaian pembelajaran yang tertuang dalam RPS pembelajaran. Capaian pembelajaran Mata Kuliah Drama dibagi menjadi dua, yaitu terkait penguasaan materi-materi atau teori dan keterampilan berpraktik atau bermain drama. Dalam RPS Mata Kuliah Drama, disebutkan bahwa teori drama diajarkan sebanyak 2 sks dan praktik 1 sks. Dari RPS Mata Kuliah Drama, didesain materi-materi yang diasumsikan sesuai dengan tujuan pembelajaran seperti sebagai berikut.

a. Judul. E-book mata kuliah Drama ini didesain dalam dua bagian, yaitu teori dan praktik. Kedua materi tersebut harus diketahui pembaca ketika melihat atau mencari e-book mata kuliah Drama ini. Oleh sebab itu, judul yang dipilih peneliti ialah "Teori Drama dan Seluk Beluk Akting”.

b. Materi Teori Drama dan seluk beluk akting. Buku ini didesain dalam lima bab. Bab pertama berisi hakikat drama. Bab kedua menceritakan sejarah perkembangan drama. Bab ketiga menjelaskan klasifikasi dan aliran dalam drama. Bab keempat dan kelima akan berfokus pada aspek praktik. Bab empat memaparkan tentang apresiasi drama dan bab lima tentang seluk-beluk akting.

c. Penggunaan Chanel youtube. Buku ini didesain untuk terhubung dengan video-video pembelajaran yang dapat disaksikan melalui chanel youtube. Oleh sebab itu, e-book mata kuliah Drama ini akan dilengkapi dengan tautan-tautan video pembelajaran yang telah dirancang sebelumnya.

d. Gambar. Bab-bab yang membahas tentang praktik bermain drama, baik itu dalam persiapan olah vokal maupun olah tubuh akan dilengkapi dengan gambar yang akan membantu pembaca dalam memahami dan menirukan gerakan yang dikembangkan. Hal ini diperlukan jika sewaktu-waktu pembaca tidak terhubung dengan akses internet.

e. Soal evaluasi. Setiap bab akan diakhiri dengan evaluasi yang dapat digunakan untuk mengukur 
Liza Septa Wilyanti, Larlen dan Irma Suryani, Pengembangan E-Book Mata Kuliah Drama sebagai Media Pembelajaran Mandiri di Masa Pandemi

pemahaman dan penguasaan mahasiswa atau pembaca tentang materi yang telah dibahas pada bab tertentu.

\section{E-book mata kuliah Drama dikembangkan} berdasarkan desain yang telah dirancang pada tahap sebelumnya. Pada tahap judul, dipikirkan pula desain sampul, huruf, dan ukuran huruf yang akan digunakan. Tahap pengembangan judul dan sampul ini melibatkan peneliti, penerbit, dan validator. Hasil diskusi dan pengembangan ditentukan bahwa bentul sampul, huruf dan ukuran yang digunakan adalah sebagai berikut.
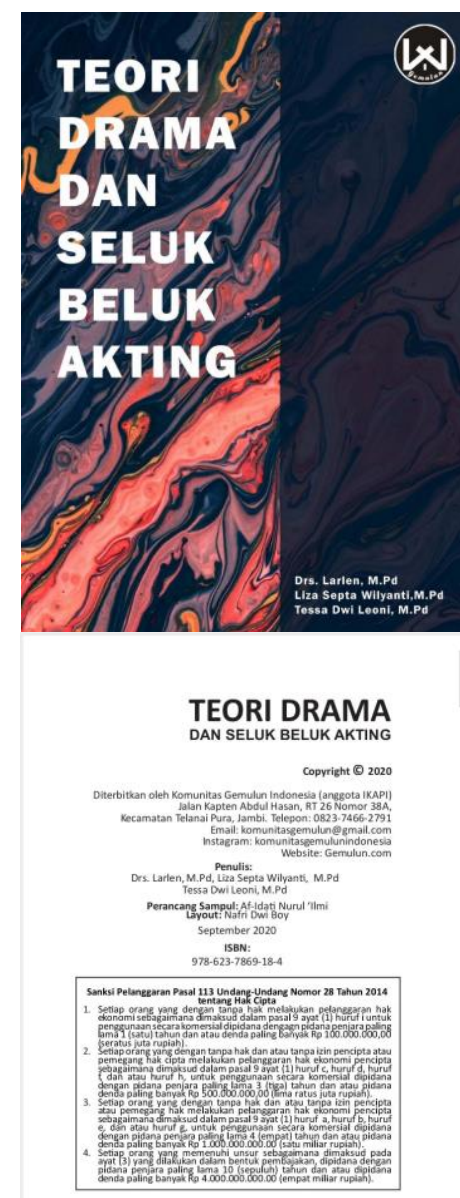

Gambar 2. Desain Sampul dan Identitas Buku

Materi-materi drama dalam buku ajar kemudian dikembangkan lebih lanjut sesuai dengan RPS seperti berikut.

Tabel 1. Pengembangan Materi Buku ajar

\begin{tabular}{llll}
\hline \multicolumn{1}{c}{ Judul Bab } & \multicolumn{3}{l}{ Materi yang Dikembangkan } \\
\hline a. Hakikat Drama & $\begin{array}{l}\text { 1. } \\
\text { 2. }\end{array}$ & $\begin{array}{l}\text { Pengertian drama } \\
\text { drama } \\
\end{array}$ \\
& & $\begin{array}{l}\text { 3. } \\
\text { drama sebagai karya dua } \\
\text { dimensi }\end{array}$ & \\
& & & \\
b. Sejarah & 1. Sejarah drama & & \\
Perkembangan & 2. Perkembangan drama di \\
Drama & & Indonesia &
\end{tabular}
c. Klasifikasi
dan 1. Klasifikasi drama
Aliran Drama
2. Aliran-aliran drama
d. Apresiasi Drama
1. Unsur-unsur pementasan drama
e. Seluk Beluk Akting
2. Proses pementasan drama
1. Pengertian akting
2. Teknik berperan
3. Olah vokal dan olah tubuh

Setelah materi dan desain sampul buku dikembangkan, berikutnya adalah memasukkan link youtube ke dalam e-book pada bagian-bagian yang dianggap sesuai. Pada latihan olah vokal dan olah tubuh akan ditautkan link https://youtu.be/4qoT-JvSOt8 dan pada pada analisis unsur drama pada video drama berbasis kearifan lokal akan ditautkan link https://youtu.be/7zwBFdFgvDk.

Pengembangan e-book mata kuliah Drama lalu dilanjutkan dengan memilih potongan-potongan gambar apa saja yang dianggap sesuai untuk melengkapi instruksi-instruksi gerakan olah vokal dan tubuh dalam buku. gambar-gambar tersebut harus mampu membantu memperjelas dan mempermudah pembaca dalam memahami dm mencontoh gerakan. Berikut beberapa potongan gambar yang digunakan dalam e-book mata kuliah Drama.

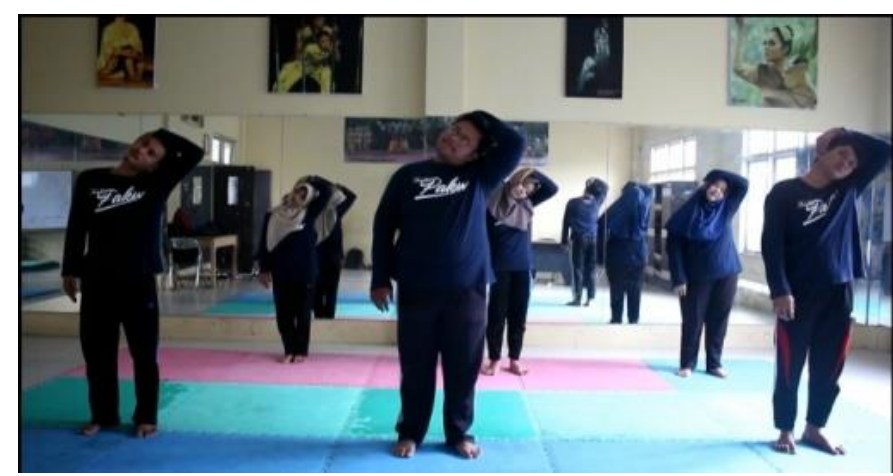

Gambar 3. Contoh pemanasan

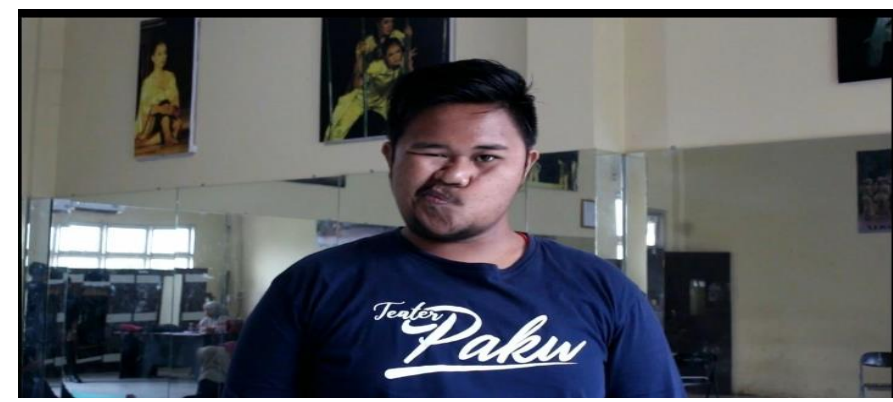

Gambar 4. senam wajah

Tahap pengembangan kemudian diikuti dengan penyusunan soal evaluasi tiap akhir bab. Setelah semua aspek pengembangan e-book mata kuliah Drama selesai, $e$-book dinilai dan divalidasi oleh seorang validator yang merupakan ahli di bidang media dan pembelajaran 
drama. Berikut tabel data hasil validasi e-book mata kuliah Drama.

Tabel 2. Penilaian Aspek Kelayakan Isi Buku

\begin{tabular}{|c|c|}
\hline Aspek yang Dinilai & Skor \\
\hline \multicolumn{2}{|l|}{ Kesesuaian Materi dengan Silabus } \\
\hline 1. Kelengkapan materi & 5 \\
\hline 2. $\quad$ Keluasan materi & 4 \\
\hline 3. Kedalaman materi & 4 \\
\hline \multicolumn{2}{|l|}{ Keakuratan Materi } \\
\hline 4. $\quad$ Keakuratan konsep dan definisi & 5 \\
\hline 5. Keakuratan prinsip & 4 \\
\hline 6. Keakuratan fakta dan data & 5 \\
\hline 7. Keakuratan contoh & 4 \\
\hline $\begin{array}{l}\text { 8. Keakuratan gambar, diagram, dan } \\
\text { ilustrasi }\end{array}$ & 5 \\
\hline $\begin{array}{l}\text { 9. Keakuratan notasi, simbol, dan } \\
\text { ikon }\end{array}$ & 4 \\
\hline 10. Keakuratan acuan pustaka & 4 \\
\hline \multicolumn{2}{|l|}{ Pendukung Materi Pembelajaran } \\
\hline 11. Penalaran (reasoning) & 4 \\
\hline 12. Keterkaitan & 5 \\
\hline 13. Komunikasi (write and talk) & 5 \\
\hline 14. Penerapan & 5 \\
\hline 15. Kemenarikan materi & 5 \\
\hline $\begin{array}{l}\text { 16. Mendorong untuk mencari } \\
\text { informasi lebih jauh }\end{array}$ & 4 \\
\hline \multicolumn{2}{|l|}{ Kemutakhiran Materi } \\
\hline $\begin{array}{l}\text { 17. Kesesuaian materi dengan } \\
\text { perkembangan ilmu }\end{array}$ & 5 \\
\hline $\begin{array}{l}\text { 18. Gambar, diagram, dan ilustrasi } \\
\text { aktual }\end{array}$ & 5 \\
\hline $\begin{array}{l}\text { 19. Menggunakan contoh kasus di } \\
\text { dalam dan luar Indonesia }\end{array}$ & 3 \\
\hline 20. Kemutakhiran pustaka & 4 \\
\hline Jumlah & 89 \\
\hline Nilai yang Diperoleh & $\frac{89}{100} \times 100 \%=89$ \\
\hline
\end{tabular}

Tabel 3. Penilaian Aspek Kelayakan Penyajian Aspek yang Dinilai Skor

Teknik Penyajian

1. Konsistensi sistematika sajian 4 dalam kegiatan belajar

2. Keruntutan penyajian

Pendukung Penyajian

3. Soal latihan pada setiap akhir bab

4. Daftar pustaka 4

Penyajian Pembelajaran

5. Keterlibatan peserta didik

Kelengkapan Penyajian

6. Bagian pendahuluan

7. Bagian isi

8. Bagian penyudah

$\begin{array}{rc}\text { Jumlah } & 33 \\ \text { Nilai yang Diperoleh } & \underline{33} \times 100 \%=82,5\end{array}$

Tabel 4. Penilaian Aspek Kelayakan Kebahasaan

\begin{tabular}{|c|c|}
\hline Aspek yang Dinilai & Skor \\
\hline \multicolumn{2}{|l|}{ Lugas } \\
\hline 1. Ketepatan struktur kalimat & 4 \\
\hline 2. Keefektifan kalimat & 4 \\
\hline 3. Kebakuan istilah & 5 \\
\hline \multicolumn{2}{|l|}{ Komunikatif } \\
\hline 4. Keterbacaan pesan & 4 \\
\hline $\begin{array}{l}\text { 5. Ketepatan penggunaan kaidah } \\
\text { bahasa }\end{array}$ & 4 \\
\hline \multicolumn{2}{|l|}{ Dialogis dan Interaktif } \\
\hline $\begin{array}{l}\text { 6. Kemampuan memotivasi pesan } \\
\text { atau informasi }\end{array}$ & 3 \\
\hline $\begin{array}{l}\text { 7. Kemampuan mendorong } \\
\text { berpikir kritis. }\end{array}$ & 4 \\
\hline \multicolumn{2}{|l|}{ Keruntutan dan keterpaduan alur pikir } \\
\hline $\begin{array}{l}\text { 8. Keruntutan dan keterpaduan } \\
\text { antar paragraf }\end{array}$ & 4 \\
\hline \multicolumn{2}{|l|}{ Penggunaan istilah } \\
\hline 9. Konsistensi penggunaan istilah & 5 \\
\hline Jumlah & 43 \\
\hline Nilai yang Diperoleh & $\frac{37}{45} \times 100 \%=82,2$ \\
\hline
\end{tabular}

Tabel 5. Penilaian Aspek Kelayakan Kegrafikan Aspek yang Dinilai Skor

Ukuran Buku

1. Kesesuaian ukuran buku dengan 5

standar penulisan buku ajar

2. Kesesuaian ukuran dengan 3 materi isi buku

Desain Sampul Buku

3. Penampilan unsur tata letak pada sampul muka, belakang dan punggung secara harmonis memiliki irama dan kesatuan (unity) serta konsisten

4. Menampilkan pusat pandang (center point) yang baik

5. Komposisi dan ukuran unsur tata letak (judul, pengarang, ilustrasi, logo, dll) proporsional, seimbang dan seirama dengan tata letak isi (sesuai pola)

6. Ukuran huruf judul buku lebih dominan dan proporsional dibandingkan ukuran buku, nama pengarang

7. Warna judul buku kontras dengan warna latar belakang

8. Tidak menggunakan terlalu 4 banyak kombinasi jenis huruf

9. Penempatan unsur tata letak konsisten berdasarkan pola

10. Pemisahan antar paragraf jelas 4

11. Penempatan ilustrasi dan keterangan gambar (caption) tidak mengganggu pemahaman

12. Penempatan judul, subjudul, ilustrasi, dan keterangan gambar tidak mengganggu pemahaman.

4

4

4

4

4


Liza Septa Wilyanti, Larlen dan Irma Suryani, Pengembangan E-Book Mata Kuliah Drama sebagai Media Pembelajaran Mandiri di Masa Pandemi

$\begin{array}{rc}\text { Jumlah } & 49 \\ \text { Nilai yang Diperoleh } & 49 \\ & 60\end{array}$ X 100\% = 81,7

Tabel 6. Hasil Validasi Buku Ajar Mata Kuliah Drama

\begin{tabular}{lc}
\hline \multicolumn{1}{c}{ Aspek yang Dinilai } & Skor \\
\hline Aspek Kelayakan Isi & 89 \\
\hline Aspek Kelayakan Penyajian & 82,5 \\
\hline Aspek Kelayakan Kebahasaan & 82,2 \\
\hline Aspek Kelayakan Kegrafikan & 81,7 \\
\hline \multicolumn{2}{c}{ Nilai Rata-Rata } \\
\hline \multicolumn{2}{c}{83,85} \\
\hline
\end{tabular}

Berdasarkan penilaian validator, aspek kelayakan isi memperoleh nilai rata-rata 89. Aspek kelayakan penyajian memperoleh nilai rata-rata 82,5. Aspek kelayakan kebahasaan memperoleh nilai rata-rata 82,2. Aspek kegrafikan memperoleh nilai rata-rata 81,7. Secara keseluruhan, nilai rata-rata yang diperoleh adalah 83,85 . Angka ini menunjukkan e-book mata kuliah Drama layak dan valid untuk digunakan.

Pada tahap implementasi ini, peneliti menyebarkan e-book mata kuliah Drama kepada 20 mahasiswa yang mengontrak mata kuliah ini. Mahasiswa yang tengah melakukan pembelajaran jarak jauh kemudian diminta untuk mengisi angket tertutup untuk menilai tingkat kepraktisan dan keefektifan buku elektronik ini. Dari hasil penyebaran angket didapatkan data berikut ini.

Tabel 7. Hasil Penyebaran Angket

\section{Aspek Yang Dinilai}

\begin{tabular}{|c|c|}
\hline \multicolumn{2}{|l|}{ Aspek Kepraktisan } \\
\hline $\begin{array}{l}\text { 1. Ukuran buku ajar mudah } \\
\text { dan dan praktis dibawa }\end{array}$ & 4,3 \\
\hline $\begin{array}{l}\text { 2. Buku ajar dilengkapi dengan } \\
\text { tautan video yang } \\
\text { memudahkan pembelajaran } \\
\text { mandiri }\end{array}$ & 4,6 \\
\hline $\begin{array}{l}\text { 3. Buku ajar dilengkapi dengan } \\
\text { tautan video yang } \\
\text { memudahkan pembelajaran } \\
\text { jarak jauh }\end{array}$ & 4,3 \\
\hline 4. Materi ajar runtut & 3,85 \\
\hline $\begin{array}{l}\text { 5. Tautan buku ajar mudah } \\
\text { diakses }\end{array}$ & 3,95 \\
\hline $\begin{array}{l}\text { 6. Gambar gerakan dalam buku } \\
\text { ajar mempermudah latihan } \\
\text { mandiri }\end{array}$ & 4,15 \\
\hline $\begin{array}{l}\text { 7. Gambar gerakan dalam buku } \\
\text { ajar mudah diikuti/dicontoh }\end{array}$ & 4,3 \\
\hline \multicolumn{2}{|l|}{ Aspek Keefektifan } \\
\hline $\begin{array}{l}\text { 8. Buku ajar menggunakan } \\
\text { bahasa yang mudah } \\
\text { dipahami }\end{array}$ & 3,8 \\
\hline $\begin{array}{l}\text { 9. Buku ajar memiliki materi } \\
\text { yang lengkap }\end{array}$ & 4,15 \\
\hline 10. Buku ajar dilengkapi dengan & 3,75 \\
\hline
\end{tabular}

\begin{tabular}{|c|c|}
\hline $\begin{array}{l}\text { gambar/contoh gerakan yang } \\
\text { mudah dipahami }\end{array}$ & \\
\hline $\begin{array}{l}\text { 11. Buku ajar menggunakan } \\
\text { sumber pustaka yang akurat }\end{array}$ & 4,15 \\
\hline $\begin{array}{l}\text { 12. Mendorong untuk mencari } \\
\text { informasi lebih jauh }\end{array}$ & 4,55 \\
\hline $\begin{array}{l}\text { 13. Kesesuaian materi dengan } \\
\text { perkembangan ilmu }\end{array}$ & 4,55 \\
\hline $\begin{array}{l}\text { 14. Gambar, diagram, dan } \\
\text { ilustrasi aktual }\end{array}$ & 4,15 \\
\hline $\begin{array}{l}\text { 15. Menggunakan contoh kasus } \\
\text { di dalam dan luar Indonesia }\end{array}$ & 3,9 \\
\hline $\begin{array}{l}\text { 16. Dilengkapi dengan evaluasi } \\
\text { di akhir bab }\end{array}$ & 4,15 \\
\hline JUMLAH & 66,6 \\
\hline Nilai yang Diperoleh & $\frac{66,6}{80} \times 100 \%=83,25$ \\
\hline
\end{tabular}

Berdasarkan angket tertutup yang telah disebarkan pada pengguna atau mahasiswa, efektifitas dan praktikalitas e-book mata kuliah Drama yang telah digunakan memperoleh nilai rata-rata 83,25. Angka ini menunjukkan buku ajar pada Mata Kuliah Drama praktis dan efektif untuk digunakan dalam pembelajaran.

\section{SIMPULAN}

Bentuk buku ajar video Mata Kuliah Drama di Program Studi Pendidikan Bahasa dan Sastra Indonesia dikembangkan dengan melihat sisi kurang dari materi teori dan keterampilan bermain drama yang sebagian besar mengalami kesulitan dalam mencari sumber belajar yang mandiri dan komprehensif. Pemanfaatan IT dalam pembelajaran praktik berdrama mempermudah mahasiswa untuk berlatih secara mandiri di manapun dan kapanpun tanpa harus bergantung pada dosen pengampu di jam perkuliahan saja. Dari hasil penelitian, diketahui bahwa buku ajar drama ini valid, praktis, dan efektif untuk digunakan. Hal itu terbukti dari hasil uji validitas buku ajar yang mendapat nilai rata-rata 83,85 dan hasil uji efektivitas dan praktikalitas sebesar 83,25.

\section{DAFTAR PUSTAKA}

Aji, Y.N.W., Heri, S. \& Maryaeni. (2017). Pengembangan Bahan Ajar Memerankan Drama Berbasis Legenda untuk Kelas VII SMP di Daerah Jawa. Jurnal Pendidikan: Teori, Penelitian, dan Pengembangan. 2 (9), 1168-1174.

Anisa, H. (2019). Teknologi dan Komunikasi Berupa Ebook Berbasis Kearifan Lokal dalam Pengembangan Bahan Ajar Bahasa dan Sastra. Jurnal Edukasi kultura. 6(1), 1-9.

Branch, R.M. 2009. Instructional Design The ADDIE Approach. New York: Springer.

Fajria, A. (2018). Persepsi Mahasiswa PBI terhadap Penerapan Pembelajaran Aktif Menggunakan Model Pembelajaran Kooperatif pada Mata Kuliah Drama, Prose, Poetry. Jurnal Lingua Applicata. 2(2), 91-110. 
Hetami, F. (2010). Resepsi Sastra dan Intertekstualitas sebagai Alternatif Pembelajaran Efektif dalam Mata Kuliah Drama Analysis. Jurnal Lembaran Ilmu Kependidikan. 39(2), 174-180.

Jannah, M. \& Muhammad, F. (2015). Pengembangan Bahan Ajar Bermain Drama Berbasis Autobiografi Habibie dan Ainun. Jurnal J-Simbol: Bahasa, Sastra, dan Pembelajrannya. 3(2), 1-10.

Ghufroni \& Moh T. (2020). Pengembangan Mata Kuliah Apresiasi dan Kajian Drama Berbasis Kebudayaan Brebes sebagai Bahan Ajar Mahasiswa. Jurnal Bahasa, Sastra Indonesia, dan Pengajarannya. 3(1), 294-303.

Khaerudin, D., Suherli K. \& Iyay Robia Khaerudin. (2019). Pengembangan bahan Ajar Menulis DramaBerdasarkan Pengalaman Pengarang sebagai Bahan Ajar Drama di SMP/MTS. Jurnal Tuturan. 8 (2), 86-95.

Kurniasih, I. \& Berlin, S. (2014). Panduan Membuat Bahan Ajar Buku Teks Pelajaran. Surabaya: Kata Pena.

Murti, S. \& Muhtadin. (2019). Validitas bahan Ajar LKS Menulis Naskah Drama Siswa Kelas VIII SMP Se-Kabupaten Musi Rawas. SILAMPARI BISA: Jurnal Penelitian Pendidikan Bahasa Indonesia, Daerah, dan Asing. 2(2), 159-172. DOI: https://doi.org/10.31540/silamparibisa.v2i2

Nainggolan, M.F. \& Erni S. (2019). Meningkatkan Keterampilan Bermain Peran Melalui Metode Role Playing Materi Memerankan Tokoh Drama Pendek. Jurnal Mutiara Pendidikan. 4(2), 1-9.

Piscayanti, K.S. (2012). Pengembangan Model Pembelajaran Sastra Berbasis Karakter dan Lokalitas dalam Mata Kuliah Drama, Jurusan Bahasa InggrisUniversitas Pendidikan Ganesha Singaraja. Jurnal Pendidikan Indonesia. 1(2), 7990.

Prastowo, A. (2014). Panduan Kreatif Membuat Bahan Ajar Inovatif. Jogjakarta: Diva Press.

Pudyastuti, M. E., Sujinah \& R. Panji, H. (2015). Upaya Peningkatan Permainan Drama pada Prodi Pendidikan Bahasa dan Sastra Indonesia melalui Lesson Study dengan Metode Brainstorming pada Mata Kuliah Penyutradaraan dan Pementasan. Jurnal Didaktis. 15(1), 1-16.

Puspitasari, D., Yunita, F., \& Muhammad, B. H. (2016). Pengembangan Buku Ajar Sastra Anak. Jurnal LPPM. 4(1), 26-33.

Soleh, D. R. \& Muhammad, B. H. (2013). Pengembangan Buku Ajar Drama Berbasis Kesenian Lokal. Jurnal Widyabastra. 1(2), 1-14.

Sugiyono, 2010. Metode Penelitian Pendidikan. Bandung: Alfabeta.

Suryani, I. \& Rasdawita. (2019). Pengembangan Bahan Ajar Menulis Naskah Drama Berbasis Pendekatan Kontekstual di FKIP Universitas Jambi. PENA:
Jurna Pendidikan Bahasa dan Sastra. 8(1), 80-92. DOI: https://doi.org/10.22437/pena.v8i1.6565

Suryanto, E. (2016). Pengembangan Materi Ajar Mata Kuliah Apresiasi Drama melalui Penggalian NilaiNilai Pendidikan Karakter Naskah Drama Panembahan Reso Karya W.S. Rendra. Jurnal Bahasa dan Seni. 44(2), 207-223.

Tomlinson, B. (2011). Materials Development in Language Teaching. UK: Cambridge University Press.

Zahroh, Hainuatus. (2017). Pengembangan Model Bahan Ajar Video Kreatif Terpimpin Edukatif (KTE) untuk Pembelajaran Menulis Karya Ilmiah Sederhana Peserta Didik Kelas IX SMP Mamba'unnur Bululawang. Jurnal Inovasi Pembelajaran. 3(1), 469-482. DOI: https://doi.org/10.22219/jinop.v3i1.4281 